Nig. J. Pure \& Appl. Sci. Vol. 34 (Issue 2, 2021)
e-ISSN 2756-4045
Life Sciences, Univ. of Ilorin, Nigeria
www.njpas.com.ng

\title{
Resource Partitioning in the Sunbird Species Found in Federal College of Forestry, Jos, Plateau State
}

\author{
Kambai Collina ${ }^{* 1}$, Olatidoye Olaremi Rebecca ${ }^{2}$, Mundi Francis Junior ${ }^{1}$, Chomini Meyiwa Stephen ${ }^{1,}$ Adedire \\ Oludare $^{3}$, and Zakariyya Ibrahim Zakariyya ${ }^{1}$ \\ Page | 4028
${ }^{1}$ Department of Forestry Technology, Federal College of Forestry Jos, Plateau state, Nigeria.
${ }^{2}$ Department of Forest Conservation and Protection, Forestry Research Institute of Nigeria (FRIN), Jericho hills, Ibadan, Oyo State, Nigeria.
${ }^{3}$ Department of Statistics, Federal College of Forestry, Jos, Plateau State.

Date Received: 20-01-2021

Date Accepted: 31-05-2021

DOI: https://doi.org/10.48198/NJPAS/21.A05

\begin{abstract}
Competition occurs when individuals or different species are vying for the same resource which is in limited supply. Two complete competitors cannot coexist indefinitely, therefore competitors must differ to some degree in their resource use. The research was carried to investigate how resources are partitioned among the species of sunbirds found in Federal College of Forestry, Jos. Opportunistic sightings along a $200 \mathrm{~m}$ transect was used for observation. Sunbirds were observed using binoculars between 6:30 - 8am and by 4:30 - 6pm. Six transects were purposively selected in the study area. Sightings along a 200m transect was used to observe; species of sunbird, sex of individual sunbird species, species of flowering plant visited by the sunbird species, activity or behaviour performed by the sunbird (probing, insect hunting, roosting, perching etc.) and duration of activity. Descriptive statistics, ANOVA and post hoc test was used to analyse the data obtained. Results showed that forty-three (43) plant species were utilised by the four (4) sunbird species found in the study site with Corymbia torelliana and Hamelia patens having the highest number of visit. These four sunbird species observed were; Scarlet-chested sunbird, Variable sunbird, Green-headed sunbird and the Copper sunbird. Mean number of plants visited shows that Greenheaded sunbird visited more plants than the other three species (28.89) which was highly significant $(\mathrm{p}=0.001)$. Copper sunbird spent the highest foraging time (67.71) which showed no variation with the other species $(p=0.516)$. Females of the sunbird species visit more plants species and spent more time foraging as compared to the males although there was no variation ( $\mathrm{p}=0.984$ and $\mathrm{p}=0.906$ respectively). The activities of the males (perching, hovering, probing, feeding) was higher than that of females and had a high level of significance $(\mathrm{p}=0.001)$. Callistemon citrinus, Corymbia torelliana, Eucalyptus camaldulensis, Hamelia patens, Parkia biglobosa and Ziziphus mucronata were utilised by all the sunbird species. Scarletchested sunbirds spent more time probing which aids pollination of plants in the study site and hence ecologically important to the plants found in the study site.
\end{abstract}

Keywords: Sun bird, Resource, Partitioning, Community, Plant

Corresponding Author: Kambai Collina

Department of Forestry Technology, Federal College of Forestry Jos, Plateau state, Nigeria.

Phone: +234-80-65359325.: Email: talk2nev@yahoo.com; kambai.c@frin.gov.ng 


\section{Introduction}

The coexistence of sympatric species is made possible by the differential utilisation of resources and niches (Fossette et al., 2017). The most Page | 4029 important limiting resources are space and food (Chapin et al., 2000) as these are the necessities for an organism to survive, grow and reproduce. Coexistence of sympatric bird species can be made possible by the partitioning of a shared habitat (Carstensen et al., 2011), the type of resource used (Beaulieu and Sockman, 2012), foraging strategy employed (Oyugi et al., 2012) or specialisation on a particular resource (Craig, 1990). Resource partitioning can result from three pressures, competition, predation and physiological constraints (Toft, 1985) and the outcome is an alleviation of the pressures of competition. If two species occupy the same ecological niche, one would eventually dominate, out-competing the weaker competitor (Griffin and Silliman, 2011). The negative effects of interspecific competition may be mitigated by species reducing the degree of overlap in their ecological niches and using resources in different ways (Ricklefs, 2007).

As food resources vary in quality, often dominant species will utilise more valuable resources, forcing subordinate species to use poorer quality resources (Abrahamczyk and Kessler, 2015). Ecological theory shows that interspecific competition will be less likely to result in competitive exclusion if it is weaker than intraspecific competition (Chesson, 2008). Resource partitioning can result in consuming slightly different forms of a limiting resource or using the same limiting resource at a different place or time, individuals of different species compete less within one another (interspecific competition) than individuals of the same species (intraspecific competition). Species therefore, limit their own population growth more than they limit that of potential competitors and resource partitioning acts to promote the large long-term coexistence (Griffin and Silliman, 2011). Floral nectar is an important food resource for many birds. Nectarivores, which often are energy limited, tend to aggregate at major blooms of certain flowers to feed and gain energy (Botes et al., 2008). Productive flowers assure these birds of stable resource sites that can be revisited repeatedly during the day for several weeks or longer. The principle that similar organisms require similar niche make competition evident. Sunbirds species are also involved in competing for limited resources such as, food, cover and mate. Lara et al. (2015) reported that species show a differential of resources in the face of interspecific competition as a fundamental manner of achieving species coexistence. In order to avoid or limit competition they often rely on resource partitioning. Sunbirds (Nectariniidae) are small bird with long curved beaks. There are many species of sunbirds and they are one of the two major groups of pollinating (flower-visiting) birds in Africa. Constantly on the move, they feed on nectar and insects and can hover around briefly (Franshawe and Stevenson, 2002).

There is no documented record on the sunbird's species found in the Federal College of Forestry Jos. The aim of this study is to determine the plant species visited by sunbird species and understand how these resources are partitioned among them. Sunbirds are recognized as very active pollinators of plants with bird pollinated flowers (Wolf et al., 2001). A vast number of experiments show that species extinction on average reduces the level of eco-system processes (Cardinale, 2006), resource partitioning is thought to play an important role in causing this effect, although ecologist are just beginning to directly test this (Griffen et al., 2008; Finke and Sander, 2008) by considering the degree of resource partitioning amongst species, scientist may be able to predict those ecosystems that are most vulnerable to the loss of species. 


\section{Materials and Methods \\ Study Area}

The study was conducted in the Federal College of Forestry Jos located on Latitude $9^{\circ} 57 \mathrm{~N}$ and Page | 4030 Longitude $8^{\circ} 54 \mathrm{E}$ on the altitude of about 1180 above sea level with mean annual rainfall of about $1250 \mathrm{~mm}$ and mean temperature of 23.5 degree (University of Jos meteorological station, 2010).

\section{Data Collection}

Sunbirds were observed using binoculars between 6:30 - 8am and by 4:30 - 6pm. Six transects were purposively selected in the study area. Sightings along a $200 \mathrm{~m}$ transect was used to observe; species of sunbird, sex of individual sunbird species, species of flowering plant visited by the sunbird species, activity or behaviour performed by the sunbird (probing, roosting, perching etc.) and duration of activity. Birds were identified with the aid of a Bird field guide (Borrow and Demey, 2004).

\section{Statistical Analysis}

Data was analysed using Statistical Package for the Social Sciences SPSS. Descriptive statistics such as bar-chart, tables and graphs were used to illustrate patterns and trends of visits to plant species. Analysis of variance (ANOVA) was used to test aspect of behaviour and visitation and their respective level of variation. Post hoc test was used to compare the level of significance between each species.

\section{Q2Results}

The result in figure 1 shows the mean number of plants visited by the sunbird species with greenheaded sunbird having the highest number (24.89) while copper sunbird had the least number (12.43) of visit to plants.

Figure 2 shows the mean number of plant visited by male and female sunbird (that is, irrespective of the different sunbird species); the females had the highest number (19.07) of plant visited while the males had the least number (19.04) of visit to plants.

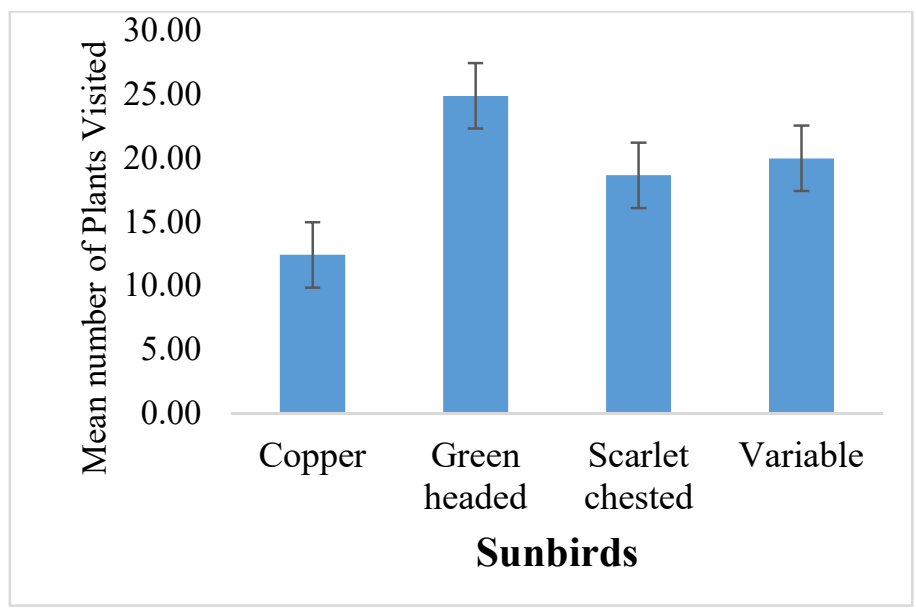

Figure 1: Mean number of plants visited by sunbird species

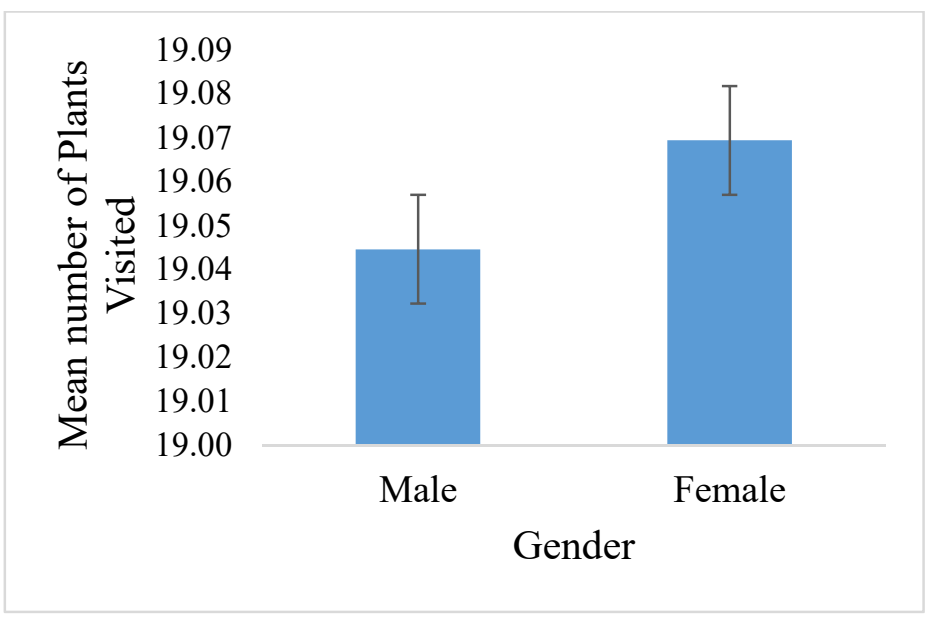

Figure 2: Mean number of plants visited by male and female sunbird

From Table 1, there was a high significant difference $(\mathrm{p}=0.001)$ between sunbird species visiting different plant species but there was no variation in the gender of sunbird species visiting plants $(\mathrm{p}=0.984)$.

Table 2 shows that the green-headed sunbird had the highest number of visit (24.89) which was significant and the least being copper sunbird which had the lowest frequency of visit (12.43). 
Figure 3 shows the mean time spent on the plants visited by sunbird species, results shows that copper sunbird spent the longest time (67.71) and lastly the scarlet-chested sunbird (51.62) which spent the least duration of time while visiting plants.

Figure 4 shows the mean time spent feeding on plants by male and female sunbird irrespective of the different species of sunbirds. The females spent the longest (58.44) while the males spent the shortest time (57.34) foraging.

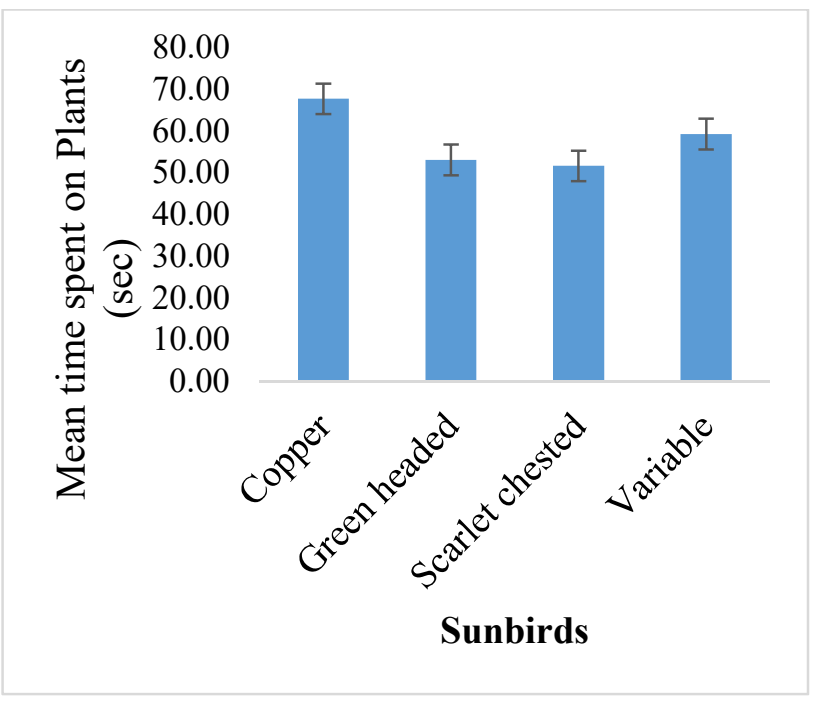

Figure 3: Mean time spent on plants by sunbird species.

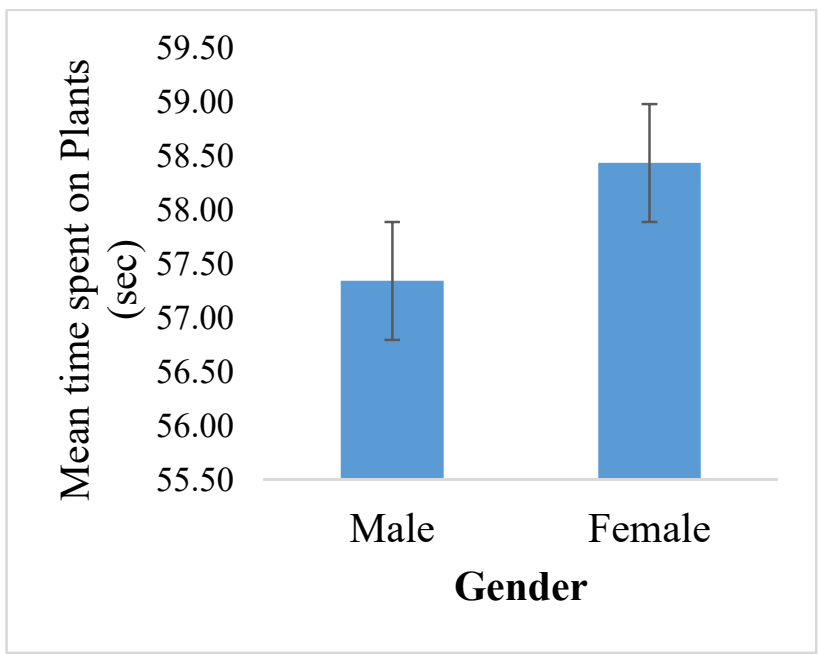

Figure 4: Mean time spent on plants by male and female sunbird
Table 3 shows that there was no variation between sunbird species visiting different plant species $(p=0.516)$ and the gender of sunbird species visiting plants $(p=0.906)$, thus the interaction between the sunbird species and gender also had no variation ( $p$ $=0.921)$

Table 4 shows that the copper sunbird had the highest number of visit (67.71) followed by the variable sunbird (59.23), then the green headed sunbird (51.62) and lastly the Scarlet-chested sunbird (51.62). All the species of sunbird had no significant difference in the amount of time spent foraging.

Figure 5 denotes the mean number of activities on plants by species with scarlet chested sunbird having the highest number of activities (1.53), while copper sunbird had the least number of activities (1.26).

Figure 6 shows the mean number of activities on plants by male and female sunbird irrespective of the species indicating the females having a greater number of activities compared to the males.

Table 5 shows the plants species highly utilised by sunbird species, with Corymbia torelliana and Hamelia patens having the highest visits (175 and 148 respectively).

Table 6 shows that more male sunbirds were encountered than females with a number of 690 and 558 respectively during the study.

Table 7 shows the number of activities by the sunbird species in the study area. Probing is the activity with the highest occurrence of seven hundred and eighty-seven sunbirds (787) while feeding had the least occurrence of one sunbird (1). Probing is an activity of searching for nectar, probing and feeding on nectar was observed mostly by Scarlet-chested sunbird. 


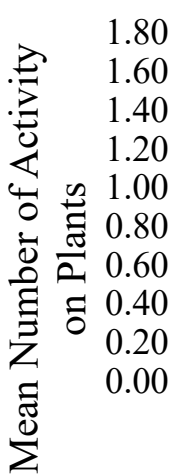

Copper Green Scarlet Variable headed chested

Sunbirds

Figure 5: Mean number of activities on plants by sunbird species.
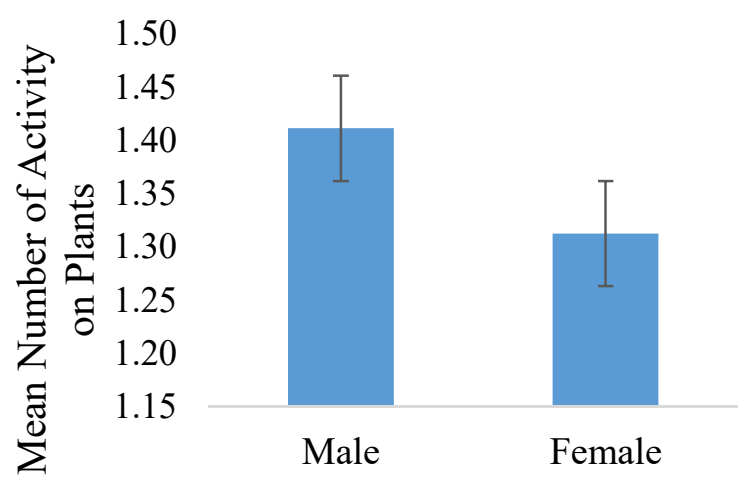

Gender

Figure 6: Mean number of activities on plants by male and female

Table 1: Analysis of Variance (ANOVA) on species and sex of sunbirds visitors on plant species

\begin{tabular}{cccccc}
\hline Source & Sum of Squares & Df & Mean Square & F & Sig. \\
\hline Sunbirds & 8845.73 & 3 & 2948.58 & 19.659 & $0.001^{*}$ \\
Gender & 0.06 & 1 & 0.06 & 0.000 & $0.984^{\text {ns }}$ \\
SB * Gender & 1197.58 & 3 & 399.19 & 2.661 & $0.047^{*}$ \\
Error & 185834.52 & 1239 & 149.99 & & \\
Total & 195582.98 & 1246 & &
\end{tabular}

Table 2: Post hoc on mean number of plant visited by sunbird species

\begin{tabular}{cc}
\hline Sunbirds & Mean Number of trees visited \\
\hline Copper SB & $12.43 \pm 8.8^{\mathrm{c}}$ \\
Green-headed SB & $24.89 \pm 12.4^{\mathrm{a}}$ \\
Scarlet-chested SB & $18.66 \pm 12.8^{\mathrm{b}}$ \\
Variable SB & $19.98 \pm 11.7^{\mathrm{b}}$ \\
\hline
\end{tabular}

Means $( \pm S D)$ in the same column having the same superscript are not significantly significant ( $p \geq 0.05)$

Table 3: Analysis of Variance on the Effects of Sunbirds Visit in relation to Time spent on plants (Seconds)

\begin{tabular}{cccccc}
\hline Source & Sum of Squares & df & Mean Square & F & Sig. \\
\hline Sunbirds & 20085.66 & 3 & 6695.22 & 0.760 & $0.516^{\text {ns }}$ \\
Gender & 122.85 & 1 & 122.85 & 0.014 & $0.906^{\text {ns }}$ \\
SB * Gender & 4303.10 & 3 & 1434.37 & 0.163 & $0.921^{\text {ns }}$ \\
Error & 10910522.76 & 1239 & 8805.91 & & \\
Total & 10935900.38 & 1246 & & & \\
\hline
\end{tabular}

Table 4: Post hoc on mean time spent on plants by sunbird species

\begin{tabular}{cc} 
Sunbirds & Mean Time Spent (Secs) \\
\hline Copper SB & $67.71 \pm 52.4^{\mathrm{a}}$ \\
Green headed SB & $53.05 \pm 47.2^{\mathrm{a}}$ \\
Scarlet chested SB & $51.62 \pm 123.6^{\mathrm{a}}$ \\
Variable SB & $59.23 \pm 55.5^{\mathrm{a}}$ \\
\hline
\end{tabular}

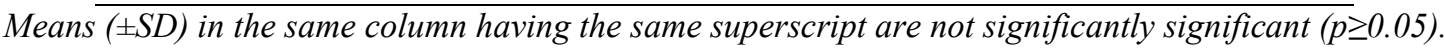


Table 5: Plant Species visited by Sunbird species in the Study Location

\begin{tabular}{|c|c|c|c|c|c|c|c|}
\hline $\mathrm{S} / \mathrm{N}$ & Plants Species & Common Names & $\begin{array}{l}\text { Copper } \\
\text { sunbird }\end{array}$ & $\begin{array}{l}\text { Green } \\
\text { Headed } \\
\text { sunbird }\end{array}$ & $\begin{array}{l}\text { Scarlet- } \\
\text { chested } \\
\text { sunbird }\end{array}$ & $\begin{array}{l}\text { Variable } \\
\text { sunbird }\end{array}$ & Total \\
\hline 1 & Albizia lebbeck & $\begin{array}{l}\text { Siris Tree, Woman's Tongue, East Indian } \\
\text { Walnut }\end{array}$ & 2 & 0 & 8 & 1 & 11 \\
\hline 2 & Anacardium occidentale & Cashew, Caju & 4 & 0 & 3 & 11 & 18 \\
\hline 3 & Bauhinia purpurea & Purple Orchid Tree; Butterfly Tree & 0 & 3 & 10 & 5 & 18 \\
\hline 4 & Caesalpinia pulcherrima & $\begin{array}{c}\text { Peacock Flower, Pride of Barbados, } \\
\text { Dwarf Poinciana }\end{array}$ & 0 & 1 & 1 & 31 & 33 \\
\hline 5 & Callistemon citrinus & $\begin{array}{l}\text { Scarlet Bottlebrush, Lemon Bottlebrush, } \\
\text { Red Bottlebrush }\end{array}$ & 2 & 1 & 81 & 20 & 104 \\
\hline 6 & Canna indica & English Indian Shot; Wild Canna Lily & 0 & 6 & 4 & 0 & 10 \\
\hline 7 & Corymbia terolliana & Cadaga, Blood-Leaf Gum & 4 & 36 & 130 & 5 & 175 \\
\hline 8 & Delonix regia & Flamboyant, Royal Poinciana & 0 & 0 & 6 & 0 & 6 \\
\hline 9 & Erythrophleum suaveolens & $\begin{array}{c}\text { English Ordeal Tree, Red Water Tree, } \\
\text { Sasswood Tree }\end{array}$ & 0 & 1 & 0 & 0 & 1 \\
\hline 10 & Eucalyptus camaldulensis & Red River Gum & 1 & 18 & 21 & 3 & 43 \\
\hline 11 & Ficus benjamina & Weeping Fig, Benjamin Fig Or Ficus Tree & 0 & 0 & 3 & 1 & 4 \\
\hline 12 & Caryota urens & Fishtail Palm & 0 & 0 & 0 & 1 & 1 \\
\hline 13 & Gmelina arborea & Gumhar, Gamhar & 0 & 0 & 8 & 5 & 13 \\
\hline 14 & Hamelia patens & $\begin{array}{l}\text { Firebush, Hummingbird Bush, Scarlet } \\
\text { Bush, And Redhead. }\end{array}$ & 18 & 2 & 16 & 112 & 148 \\
\hline 15 & Jacaranda mimosifolia & Blue Jacaranda, Fern Tree & 0 & 2 & 15 & 10 & 27 \\
\hline 16 & Jatropha curcas & Purging Nut, Barbados Nut Or Physic Nut & 0 & 0 & 1 & 5 & 6 \\
\hline 17 & Canna indica & Indian Shot, African Arrowroot & 0 & 1 & 1 & 0 & 2 \\
\hline 18 & Khaya grandifolia & $\begin{array}{l}\text { Broad-Leaved Mahogany, Benin } \\
\text { Mahogany, Benin Wood }\end{array}$ & 0 & 0 & 0 & 2 & 2 \\
\hline 19 & Khaya ivorensis & $\begin{array}{l}\text { Lagos Mahogany, Lagos Wood, Red } \\
\text { Mahogany }\end{array}$ & 0 & 1 & 9 & 1 & 11 \\
\hline 20 & Khaya senegalensis & Senegal Mahogany, Dry Zone Mahogany & 0 & 1 & 11 & 6 & 18 \\
\hline 21 & Lantana camara & Lantana Weed, Wild Sage & 0 & 0 & 3 & 3 & 6 \\
\hline 22 & Leucaena leucocephala & Leucaena, Lead Tree, White Tamarind & 1 & 1 & 9 & 16 & 27 \\
\hline 23 & Zea mays & Maize & 0 & 10 & 19 & 8 & 37 \\
\hline 24 & Mangifera indica & Mango & 0 & 0 & 4 & 0 & 4 \\
\hline 25 & Maranthes polyandra & Maranthes & 0 & 0 & 11 & 32 & 43 \\
\hline 26 & Moringa oleifera & $\begin{array}{l}\text { Drumstick Tree, Miracle Tree, } \\
\text { Horseradish Tree, Benzolive Tree. }\end{array}$ & 0 & 0 & 2 & 0 & 2 \\
\hline 27 & Parkia biglobosa & African Locust Bean & 1 & 13 & 80 & 4 & 98 \\
\hline 28 & Pavetta spp. & Bride's Bush, Christmas Bush & 0 & 0 & 0 & 3 & 3 \\
\hline 29 & Pinus caribea & Black Pine & 0 & 0 & 0 & 7 & 7 \\
\hline 30 & Polyalthia longifolia & Cemetery Tree, Indian Fir, Mast Tree & 0 & 0 & 3 & 3 & 6 \\
\hline 31 & Saba comorensis & Rubber Vine & 0 & 0 & 7 & 13 & 20 \\
\hline 32 & Senna siamea & $\begin{array}{c}\text { Cassod Tree, Siamese Cassia, Blackwood, } \\
\text { Iron Wood, Yellow Cassia }\end{array}$ & 0 & 0 & 1 & 0 & 1 \\
\hline 33 & Spathodea campanulata & African Tulip Tree & 1 & 90 & 34 & 4 & 129 \\
\hline 34 & Stenolobium stans & $\begin{array}{l}\text { Yellow Elder, Yellow-Trumpet Flower, } \\
\text { Trumpet Bush }\end{array}$ & 0 & 1 & 11 & 32 & 44 \\
\hline 35 & Tectona grandis & Teak & 0 & 0 & 3 & 0 & 3 \\
\hline 36 & Terminalia mentaly & Madagascar Almond & 0 & 0 & 21 & 11 & 32 \\
\hline 37 & Terminalia catappa & $\begin{array}{l}\text { Country Almond, Indian Almond, } \\
\text { Malabar Almond, Sea Almond, Tropical } \\
\text { Almond, Beach Almond }\end{array}$ & 0 & 0 & 0 & 1 & 1 \\
\hline 38 & Terminalia superba & Afara, White Afara & 0 & 0 & 5 & 1 & 6 \\
\hline 39 & Thevetia peruviana & Yellow Oleander, Lucky Nut & 0 & 29 & 33 & 15 & 77 \\
\hline 40 & Thuja plicata & Western Red Cedar & 0 & 0 & 0 & 5 & 5 \\
\hline 41 & Vitellaria paradoxa & Shea Tree, Sheabutter Tree. & 0 & 0 & 0 & 2 & 2 \\
\hline 42 & Vitex doniana & Black Plum. & 0 & 0 & 16 & 5 & 21 \\
\hline 43 & $\begin{array}{c}\text { Ziziphus mucronata } \\
\text { Total }\end{array}$ & Buffalo Thorn; Cape Thorn & $\begin{array}{c}1 \\
35\end{array}$ & $\begin{array}{c}3 \\
220\end{array}$ & $\begin{array}{c}9 \\
599\end{array}$ & $\begin{array}{c}10 \\
394\end{array}$ & $\begin{array}{c}23 \\
1248\end{array}$ \\
\hline
\end{tabular}


Table 6: Gender Distribution of the Sunbirds

\begin{tabular}{cc}
\hline Gender & Frequency \\
\hline Male & 690 \\
Female & 558 \\
Total & 1248 \\
\hline
\end{tabular}

Page | 4034

Table 7: Sunbird species activities on the individual plant's species

\begin{tabular}{cccccc}
\hline & \multicolumn{5}{c}{ Sunbirds } \\
Activity on Plant & Copper & Green-headed & Scarlet-chested & Variable & Total \\
\hline Probing & 26 & 136 & 337 & 288 & 787 \\
Perching & 9 & 82 & 235 & 99 & 425 \\
Feeding & 0 & 0 & 1 & 0 & 1 \\
Hovering & 0 & 2 & 26 & 7 & 35 \\
Total & 35 & 220 & 599 & 394 & 1248 \\
\hline
\end{tabular}

\section{Discussion}

At the completion of the research, four sunbird species were found in the study site (Scarletchested, Green-headed, Variable and Copper sunbird). The identified plant species visited by the sunbirds in the study area were about fortythree (43). Hamelia patens had the highest visitation rate, Variable sunbird had the highest frequency of visit (112) to Hamelia patens while Green-headed sunbird has its highest visit to Spathodea campanulata and Scarlet-chested has its highest visit to Coryambia terolliana (90 and 130 respectively). Only six (6) plant species were visited by all the sunbird species found in the study site (table 6) which includes; Callistemon citrinus, Corymbia torelliana, Eucalyptus camaldulensis, Parkia biglobosa, Hamelia patens and Ziziphus mucronata. Scarlet-chested sunbird visited the first three plant species more than other sunbirds species while the variable sunbird visited the last two plant species more frequently.

According to Wilmer (2011), flowers differ in their morphology in several ways (tube-like structure to narrow tubes spiral shapes funnellike, brush-like, among others), colour and floral structure including nectar production structure are some of the main factor determining the types of bird visitor that patronizes a flower. Plants may invest more in to floral structure in other to attract one particular bird visitor more than another (Stiles, 1978; Wilmer, 2011). Thus, it has been observed that different floral structure attracts different type of bird visitor which may suggest the reason why the studied sunbird species frequently visited/preferred visiting different flowers. The sunbirds visited different plant species or the same plants at the same time interval by utilizing different parts of the plants, sometimes if a particular species is probing for nectar the other species will be seen perching on other parts of the tree, which indicates that some species can coexist by having different niches on a particular food resource (tree) which must not overlap to avoid competition, as it was observed that copper sunbird and variable sunbird visited Hamelia patens same time but while the copper probe the variable sunbird perches or hover around it. This result agrees with Gaus (1934) who stated that "two complete competitors cannot coexist indefinitely therefore competitors must differ to some extent in their resource use". Furthermore, the result obtained in this study shows that each of the sunbird species in the study area visit a particular plant species more often than others for instance, the Variable sunbird visited Hamelia patens (table 6) more often than any other species and also spent the longest time 
Page | 4035 other species and perhaps the nectar quality or quantity of the plant may be low so it needs to spend a longer time foraging to meet it diet requirement. This is in line with the statement that 'When the nutrient or energy content of a food source is low, animals ingest larger amount, which is commonly known as compensatory feeding, and can be observed in various animal's taxa' (Karasov and Martinez Del Rio, 2007). Animals also increase their food intake after a period of deprivation to compensate for an energy deficit. The widespread distribution of the compensatory feeding response demonstrates the importance of the regulation of energy intake for animal survival and fitness. The energy that animals gain from their food however is determined not only by their foraging decision, but also by the digestive process of food. The macro nutrients (carbohydrate, protein and lipids) present in ingested food need to be broken down in to their smallest components, a process that involves numerous enzymatic pathways. The breakdown products are subsequently absorbed by the epithelium of the gastrointestinal tract, either passively by diffusion or actively via carrier-mediated mechanism (Karasov and Martinez Del Rio, 2007).

Green-headed sunbird was observed to be highly territorial; it chases away any other sunbird species that utilises the same tree. Scarlet-chested sunbird also, chases away variable sunbird. This is in line with the finding by Schemer (1994) who stated that the coexistence of sympatric species is made possible by the differential utilization of resources and niches.

Mean number of plant visited by species from the result obtained shows that Green headed sunbird visits more plants than the other three species which was highly significant $(\mathrm{p}=0.001)$ as shown in figure 1 and table 1 above. This may be due to the fact that different birds have different nectar requirement as nectar varies in sugar concentration and viscosity. Plants pollinated by birds are expected to produce higher volumes of more diluted nectar than plants pollinated by insects (Bolten and Feinsingar, 1998; Nicolson and Fleming, 2003; Gold blatt and Manning, 2008).

Female sunbird species visited more plants and spent more time foraging than the males (Figure 4) which could be due to the fact that females go out to look for food and feed the fledglings (young birds) while the males watch over at home and protect their territories. Another reason may be to avoid competition as males are known to be more aggressive. The principle that similar organisms require similar niche makes competition evident, sunbirds are not exception to this; hence in event of competition different species device difference means or strategy to cope with competition for limiting resources. Lara et al. (2015) reported that species show a differential use of resources in the face of competition as a fundamental manner of achieving species coexistence. It was also observed that male sunbird species conduct more activities such as probing, hovering, etc. than the females, which may be due to factors such as mating and territoriality by the male sunbird species. Also, the males of the sunbird species had a higher level of occurrence as compared to the females in the study site (figure 6) with the level of occurrence of the females being 558 while the male was 690 .

It was also observed that Green-headed sunbird visited more plants but doesn't spent much time foraging while copper sunbird visits a very few number of plants but spends the highest time foraging after which it hides (roosts) as it had the lowest number of activity recorded as compared to other sunbird species. Variable sunbird also visits numerous numbers of plants and also spends 
Page | 4036 as compared to other sunbird species (Figure 1,3, and 5), but was observed to have the greatest level of activities (probing, feeding, hovering and perching) and the highest level of occurrence which is highly significant as compared to other sunbird species. The level of occurrence may be the reason why they do not need to spent much time feeding on numerous plants as their numbers as high they can easily share their resources as they were observed to be the most-friendly species that are not territorial, although there may be high predation risk if they are known to be very active. Scarlet-chested sunbird was observed to probe plants more frequently than other sunbird species which is very important in pollination (self and cross), hence it is a vital species (keystone species) in the study site.

\section{Conclusion}

Four (4) sunbird species; Scarlet-chested sunbird, Green-headed sunbird, Variable sunbird and Copper sunbird were found in the study site. These species utilised resources in different ways so that they can coexist, some species fed on numerous plants within a short time to avoid predation pressure while other feed on less plant species within a short time because they have a high population that can withstand predation. The activities of sunbird species on a plant at the same time vary with each species having its niche. Scarlet-chested sunbirds were observed to probe more plants which was highly significant and of great ecological value, in both self and cross pollination. Plants species frequently utilised by the sunbird species had colourful and attractive flowers such as; Corymbia terroliana, Hamelia patens and Spathodea campanulata. There is need to plant more of these so that the species of sunbirds which are excellent pollinators can be conserved.

\section{Competing interests}

The authors declare no conflict of interest. This study was funded by the authors. No financial assistance was gotten from any funding agency or Institution.

\section{References}

Abrahamczyk, S. And Kessler, M. (2015). Morphological and behavioural adaptations to feed on nectar: how feeding ecology determines the diversity and composition of hummingbird assemblages. Journal of Ornithology, 156: 333-347.

ABC (2007). ABC Bulletin. Pp. 109 - 110.

Abed, C. R. and Mann, C. (2008). Family Nectariniidae (sunbirds). Handbook of the bird of world: lynx Edicios. pp. 33, ISBN 196-84-96554-45.

Abundsey, T. (1991). Encyclopaedia of animals; Birds London; merefiurst press, pp. 207.ISBN 1-85391-186-0.

Barbosa, A. and Moreno, E. (1999). Evolution of foraging strategies in shorebirds. Angeomorphological approach, Auk, 166 (3):712-725.

Beaulieu, M. and Sockman, K.W. (2012). One meadow for two sparrows: resource partitioning in a high elevation habitat. Oecologia 170: 529-540.

Bibby, C.J., Burgess, N.D. and Hill, D.A. (1992). Bird Census Techniques, Acadamic Press, London.

Borrow, N. and Demey, R. (2004). London, UK: Christopher Helm. Pp.512. ISBN 0713666927. 
Botes, C., Johnson, S.D. and Cowling, R.M. (2008). Coexistence of succulent tree aloes partitioning of bird pollinators by floral traits and flowering phenology. Oikos, $117(6) ; 875-882$.

Page | 4037

Brown, J.H. and Brown, A.K. (1979). Convergence, competition and mimicry in a temperate community of hummingbirdpollinated flowers. Ecology, 60(5): 10221035. http://dx.doi.org/10.2307/1936870

Cardinal, M.V., Castena, M.B., Lauricella, M.A., Cecere, M.C., Ceballos, L.A., Vazquezprokopec, G.M., Kitrori, U. and Gurtler, R.E. (2006). A prospective study of the effects of sustained vector surveillance following community-wide insecticide application on Trypanosoma cruz infection of dogs and cats in rural north western Argentina. American journal of tropical medicine and hygiene, 75(4):753-61.

Carstensen, D. W., Sweeny, R., Ehlers, B. and Olesen, J. M. (2012). Coexistence and habitat preferences of two honeyeasters and a sunbird on Lombok, Indonesia. Biotropica, 43:351-356

Chapin III, F., Zavaleta, E., Eviner, V., Naylor, R., Vitousek, P., Reynolds, H., Hooper, D., Lavorel, S., Sala, O., Hobbie, S., Mack, M. and Diaz, S. (2000). Consequences of changing biodiversity. Nature, 405: 234 242. https://doi.org/10.1038/35012241

Chapman C.A. and Chapman L.J. (1997). Forest regeneration in logged and unlogged forests of Kibale National Park, Biotropia, 29(4): 396-412. http://dx.doi.org/10.1111/j.17447429.1997.tb00035.x

Chesson, P. (2006). Mechanison of maintenance of species diversity. Annual Review of Ecology and Systematics, 31: 343-366.
Cody, M.L. (1968). Interspecific territoriality among humming bird species. Condor, 70 : 270-271.

Craig, R.J. (1990). Foraging behaviour and microhabitat use of two species of whiteeyes (zesteropidae) on Saipan, Micronesia. AUK, (3): 500.

Forsette, S., Abraham, B., Hazen, E.L., Bograd, S.J., Zilliacus, K.M., Calambokidir, J., Burrows, J.A., Goldbogen, J.A., Harvey, J.T., Marinovic, B., Tershy, B. and Croll, D.A. (2017). Resource partitioning facilitates coexistence in sympatric cetaceans in the California current. Ecology and Evolution, 7(21): 9085 -9091.

Finke, D.L. and Synder, W.E. (2008). Niche Partitioning increases resources exploitation by diverse communities'. Science, 321; 1488-1490.

Frost, S.K. and Frost, P.G.H. (1980). Territoriality and changes in resource use by sunbirds Leonotisleonurus (Labiatae), Oecologia, 45(1): 109-116. http://dx.doi.org/10.100 7/BF00346715

Fry, C.H., Keith, S. and Urban, E.K. (2000). The birds of Africa, vol. 6, Picathartes to Oxpeckers.

Gass, C. L. (1978). Rufous humming birds feeding territoriality in suboptimal habitat.Journal of zoology, 56: 1535-1539.

Gause, G. (1934). The struggle for existence (1 ed.). Baltimore, Maryland: Willams and Wilkins Co.

Gill, F.B. (1978). Proximate costs of competition for nectar. Amer. Zool., 18(4): 753-763. http://dx.doi.org/10.1093/icb/18.4.753

Gill, F.B. and Wolf, L.L. (1978). Competitive foraging efficiencies of some Montane 
sunbirds in Kenya, Condor, 80(4): 391-400. http://dx.doi.org/10.2307/1367189

Gill, F.B. and Wolf, L.L. (1979). Nectar loss by Golden-winged sunbirds to competitors.Auk, 96(3): 448-461.

Griffin, J.N. and Silliman, B.R. (2011). Resource partitioning and why it matters. Nature Education Knowledge, 3(10): 49.

Griffin, J. N., de la Haye, K. L., Hawkins, S. J., Thompson, R. C. and Jenkins, S. J. (2008). Predator diversity and ecosystem functioning: density modifies the effect of resource partitioning. Ecology, 89: 298305.

Kato, M., Takao, I. and Toroyoshi, N. (1993). Mellittophily and Ornithophily of long-tube flowers in Zingiberaceae and Gesneriaceae in West Sumatra. Tropics, 2: 129-142. http://dx.doi.org/10.3759/tropics.2.129.

Krasov, W.H. and Martinez Del Rio, C. (2007). Physiological ecology. How animal process energy, nutrients and toxins Princeton University press, New Jersey, USA.

Karasov, W. H. (1996). Digestive plasticity in avian energetics and feeding ecology. Avian Energetics and Nutritional Ecology (C. Carey, ed.). Chapman and Hall, New York, 61-84pp.

Knight, T.M., Steet, J.A., Vamosi, J.C., Mazer, S.J., Burd, M., Campbell, D.R., Dudash, M.R., Johhnston, M.O., Mitchell, R.J. and Ashman, T.L. (2005). Pollen limitation of plant reproduction: Pattern and process.Annual Review of Ecology, Evolution, and Systematics, 36:467-497 .

Kudom, A.A. and Kwapong, P.K. (2010). Floral visitors of Ananascosmosus in Ghana: A preliminary Assessment. Journal of Pollination Ecology, 2: 27-32.
Lara, C.I., Perez, B., Castillo- Guevara, C. and Serrano-menesses, M.A. (2015). Niche partitioning among three-climbing. Bird species in sub-tropical mountains forest site with different human disturbances, Zool. Stud., 54:28. http://dx.doi.org/10.1186/s4 0555-015-0106-y

Laubhann, D. and Puff, C. (2002). Birds and bird colours, Flowers pollinated by birds: diaspores dispersed by birds, Example from the flora of Thailand.

Pickens, A.L. (1951). Red and red-kin colors in bird-visited flowers. Castanea, 16 (3): 105 109

Pyke, G.H. (1982). Local geographic distributions of bumblebees near Crested Butte, Colorado: competition and community structure. Ecology, 63: 555573. http://dx.doi.org/10.2307/1938970

Pyke, G. H. (1981). Optimal nectar production in a hummingbird plant. Theoretical Population Biology, 20:326-343.

Pyke, G. H. (1982). Foraging in bumblebees: rule of departure from an inflorescence. Canadian Journal of Zoology, 60: 417-428.

Raven, P.H. (1972). Why are bird-visited flowers predominantly red? Evolution, 26(4): 674. http://dx.doi.org/10.2307/2407064

Schoener, T.W. (1974). Resource partitioning in ecological communities, Science, 185: 27 39. http://dx.doi.org/10.1126/science.1 85.4145 .27

Starck, J. M. (1999). Phenotypic flexibility of the avian gizzard: rapid, reversible and repeated changes of organ size in response to changes in dietary fibre content. Journal of Experimental Biology, 202:3171-3179. 
Stiles, F.G. (1978). Ecological and Evolutionary Implications of Bird Pollination. Integrative and Comparative Biology, 18(4):715-727

Morse, D.H. (1974). Niche breadth as a function of social dominance. American naturalist, 108(964), 818-830.

Nicolson, S.W. and Fleming, P.A. (2003). Nectar as food for birds: the physiological consequences of drinking dilute sugar solutions. Plant Systematics and Evolution, 238 (2003), pp. 139-153.

Nicolson, S.W. and Fleming, P.A. (2003). Energy balance in the White-bellied Sunbird Nectariniatalatala: constraints on compensatory feeding, and consumption of supplementary water. Functional Ecology, 17 (2003), pp. 3-9.

Oyugi, D. O. (2012). Ecological impacts of the invasive common carp (Cyprinus carpio L.), on naturalised fish species in Lake Naivasha, Kenya. Unpublished PhD Thesis, School of Biological Sciences, University of Nairobi, Nairobi: 279 pp.

Shoener, T.W. (1974). Resources partitioning in ecological communities.Science, 185 (4145), 27-39.
Toft, C.A. (1985). Resource partitioning in amphibians and reptiles. Epeia, 1-21.

Wilmer, P. (2011). Pollination and floral ecology, Princeton University Press, London. http://dx.doi.org/10.1515/9781400838943.

Whimberly, M.C and Spies, T.A. (2001). Influences of environment and disturbance on forest patterns in Coastal Oregon watersheds. Ecolog, 82 (5): 1443 - 1459.

Wolf, L.L., Hainsworth, F.R. and Gill, F.B. (1975). Foraging efficiencies and time budgets in nectar feeding birds. Ecology, 56 (1); $117-128$

Wolf, M. M. (1978). Social validity: The case for subjective measurement or how applied behavior analysis is finding its heart. Journal of Applied Behavior Analysis, 11(2), 203-214. https://doi.org/10.1901/jab a.1978.11-203. 